\title{
Complacent Effect of Age and Education on the Online Banking-Service Compatibility: Study in Delhi and National Capital Region
}

\author{
Ankur Agrawal ${ }^{1}$, Mohammad Rumzi Tausif ${ }^{2}$, Prashant Kumar Pandey ${ }^{3}$, \\ Praveen Kumar Pandey ${ }^{4}$
}

\author{
${ }^{1}$ School of Business Studies, Sharda University, Greater Noida, 201310, India \\ ${ }^{2}$ College of Business Administration at Prince Sattam Bin Abdulaziz University, Al Kharj, Kingdom of Saudi Arabia \\ ${ }^{3}$ Amity International Business School, Amity University, Noida, 201313, India \\ ${ }^{4}$ School of Business Studies, Sharda University, Greater Noida, 201310, India
}

\begin{abstract}
This study aims to determine the effect of age and education on the customers' service compatibility and determine the awareness level of the banking customers related to the banking services. The collection of data will be a blend of primary and secondary sources based on private banks. Based on the findings, it can be said that gender affects service compatibility with the user. Still, the education level has no direct effect on compatibility.
\end{abstract}

Keywords: e-banking, online banking, service quality, compatibility, private banks.

\section{Introduction}

Online banking is a flood without limits. It gives customers immense points of interest to the extent of straightforwardness and cost trades through the web, telephone, or other electronic transport. Esupport joins the online portion, web trading, and web dealing with a record [1], [2].

DOI: $10.18421 /$ TEM94-59

https://doi.org/10.18421/TEM94-59

Corresponding author: Praveen Kumar Pandey,

Management Professional, School of Business Studies,

Sharda University, Greater Noida, India, 201310.

Email: praveen.pandey2022@gmail.com

Received: 05 August 2020.

Revised: 05 November 2020.

Accepted: 11 November 2020.

Published: 27 November 2020.

(cc) BY-NC-ND(C) 2020 Praveen Kumar Pandey et al; published by UIKTEN. This work is licensed under the Creative Commons Attribution-NonCommercial-NoDerivs 4.0 License.

The article is published with Open Access at www.temjournal.com
The electronic reserve has wound up a champion among the most urgent mechanical changes in the financial business. "E-finance" provides convenience to customers in cash possession and transfers through electronic correspondence [2].

Furthermore, web dealing with a record implies retail and little regard setting aside cash things and organizations through electronic channels and farreaching worth electronic portions and other discount setting aside cash organizations passed on electronically [11]. Regardless of how the customers have had a great time, uncommon solace of web dealing with a record and speculators have upgraded the banks' cost-viability [10]. It incorporates individual and corporate clients and consolidates bank trade, portions, account assembling and credits, corporate and nuclear family advancing, card business, etc. As demonstrated by the Bank for Worldwide Settlement definitions, the online portion makes huge efficiencies and is better than the regular paper-based course of action. Web trading is implanted as a comprehensive arrangement of structures that electronically distribute pre-trade and post-trade information.

\subsection{Objective of the Study}

1. To determine the awareness level of the banking customers related to the banking services.

2. To determine the effect of age and education on the service compatibility of the customers.

\subsection{Gap Analysis}

The banking services are a bit complicated and sometimes tedious because of technological processes and customers' compatibility. Such services require the savviness of technology among users to operate better. So, the effect of age and education on the banking services' compatibility is covered in this study. The study will encompass the 
estimation of banking customers' awareness about the variety of banking services and even usercompatibility.

\section{Review of the Literature}

\subsection{The Background of Internet}

It is said that the need is the mother of advancement in electronification. Additionally, certifiable, it is the implantation of the web in the slag of the universal war. Likewise, a champion among the essential imperative issues was -"The way would powerful countries talk with one another in the result of a nuclear ambush? "PCs were by then there. Regardless, correspondence was related to one another in a personal style in a sort of chains: genuinely like an electrical cable to our home. So for quite a while after the war, by far, most of the United States' military investigation concentrated on the ways and plans to endure the nuclear holocaust. This suggests that if even one chain in the inside detonated, the whole framework would disintegrate.

At that point in the 1960's the issue was taken by America's preeminent military research organization, the Rand Corporation. After a ton of thoughts were set up and thumped down, Paul Baron-a rand "mastermind," hit upon an idea. "Imagine a scenario in which the system was not fabricated like a chain but rather like a fish net?" he said. If one strand on the fishnet broke, the net would, at present, be utilitarian. By then, youthful designers were inspired by the thought and took a shot at it. Before the end of the decade, the main net was made and called Arpanet, interfacing four American exploration Associations: the University of Utah and the University of California in Los Angeles and Santa Barbara, and Stanford research organization.

\subsection{The Background of Online Banking}

"Online Banking" at first picked up prevalence in the late 1980s, the expression alluded to the utilization of a terminal, console and TV or PC screen to get to one's financial balance utilizing a landline phone. The early form of what was viewed as web saving money started in 1981. New York City was the primary spot in the U.S. to try out the creative method for working together by giving remote administrations as four of its significant banks - Citibank, Chase Manhattan, Chemical Bank and Manufacturers Hanover - made home keeping money access accessible to their clients. In October 1994, Stanford Federal Credit Union turned into the primary money related establishment in the U.S. to offer web saving money to the greater part of its clients. After a year, Presidential Bank turned into the main bank in the nation to offer clients access to their records on the web.

\subsection{Studies Related to Banks}

In the investigation surveyed, the open entryways for utilizing the web concerning the financial business. They studied that legitimate usage of the present cutting edge advancement could ensure the banks' accomplishment in the engaged business division [3]. The makers dismembered that trades by methods for the web to decrease data mishap risk to customers, the chance to slash down costs, a higher flexibility for bank laborers, re-shaping the banks' image into a creative and precisely driving foundation, etc.

Author Analysis- Association with the systemadmittance, will assist to succeeds in an account with poignant well elsewhere and mark their name in the future dazzling structure.

In his researched paper, he examined the factors affecting the gathering of web dealing with Australian customers' records. The examination of the investigation research exhibited that security concerns and nonattendance of care rise as the clarifications behind the non-choice of online banking by Australian customers. The maker interconnected that the web and other virtual dealings with a record had, by and large, cut down the cost applicability [15]. This way, the banks should ask customers to use the web for setting aside cash trades.

Author Analysis - Internet office with full security measures and terms and conditions could help the speedy, swift movement of customers to web dealing with a record realizing saving of banks' happenings costs.

Another study is considered by Jordan banks. This study explored the clarifications for giving ebanking services, their impact on dealing with a record organization, and banks' profitability explicitly [16]. The investigation's eventual outcomes revealed that electronic keeping cash organizations adversely influenced the banks' competence in the short run because of the extended capital costs required in the explicit and electronic base, the charge of planning to laborers. Moreover, the price is needed to create conditions where the banks can work without any problem [16]. In any case, these organizations had a beneficial outcome as time goes on, the banks' advantage.

Author Analysis - The banks need to do care and headway campaigns to show clients and alert them of credibility through reduced time, cost, challenges besides holding instructional classes for laborers to appreciate the web setting aside the cash business frameworks. 


\subsection{Studies Related to Customers}

The investigation relied upon a sample of 300 bank customers. It revealed that $90 \%$ of respondents visit their bank workplaces at least once every week, $63.3 \%$ of customers exhibited at least four visits to ATMs regularly, and $20 \%$ of the respondents were using online banking. Investigated e-banking's headway in Malaysia and separated the diverse electronic transport channels used by neighborhood banks to assess the client's reaction to these movement channels. The study's objective was to introduce the dynamic headway of e-dealing with a record, electronic movement channels, and related issues for effective execution of e-setting aside cash [7]. Only $6.7 \%$ of customers demonstrated that they would not be captivated at all using these organizations. The results exhibited that among different channels of e-dealing with a record like flexible keeping cash, ATMs, PC banking, the ATMs are the most commonly recognized by everybody [7]. The authority moreover found that bank workplaces and collaboration with human tellers were as yet essential. $60 \%$ of the respondents had web access at home, and it thus presents a positive indication of the PC keeping cash in the future.

Author Analysis - For effective execution of edealing with a record, the significant prefundamentals was legitimate and physical establishment since e-keeping cash requires a considerable amount of imperceptible and creative changes in banks.

The makers grasped the advancement affirmation model to impact the online condition. The model showed e-banking among hidden overseeing account customers in Finland through a model examination [12]. It featured that electronic keeping cash advancement had improved methodologies for consistently dealing with a record, especially by methods for web-settled banking channels. The revelations of the examination exhibited that the noticeable worth, information on the web keeping cash, security and assurance, nature of the organization, convenience on the webpage were the essential factors affecting web dealing with a record affirmation.

Author Analysis - Banks should now increasingly spotlight their e-keeping cash issues to set aside cash that could end up being progressively well known and adaptable for customers.

The maker took a gander at the ordinary and saw E-banking estimation through mean responses, which showed that most significant irregularities were found in the availability of bearings and personnel help on the ideal approach to using ekeeping cash organizations helpfulness [4]. Given the contention, the banks brought to the table a progressively broad extent of things and organizations at increasingly engaged expenses through progressively beneficial and worthwhile channels. The investigation explored the dissimilarity between customer want wishes and acknowledgment toward web banking services.

Author Analysis - To extend the general organization nature of web banking, organization and laborers should find what customers expect to develop framework giving, capability, accessibility, and overhauled information about things and organizations.

\subsection{Studies Related to Service Quality}

One study proposed a structure for delineating why clients utilize electronic overseeing account things, such as electronic bill portion, credit card, debit cards, and e-cash to set aside cash needs. The development towards electronic setting aside cash things was progressively dependent on working up business cases rather than vanquishing purchaser aversion. The maker explained that purchaser direction was consistent with their tendency, which joins convenience, sparks, control, assurance, security and workforce commitment [9]. The paper recommended that clients choose offset decisions to use an alternative of E-banking instruments rather than irrationally impenetrable to change.

Author Analysis - Greater control, solace and correspondence power were a couple of reasons which made the purchasers' development to electronic portion things.

It explained the possibility of e-dealing with a record and featured all of the concerns and threats while implementing the equivalent. The reviewers said that e-dealing with a record was not merely to improve the idea of organizations rendered to the patrons but also to promulgate things better [14]. The makers graphed assorted e-saving cash modems for administration account trades like PC, ECS, ATM, EFT setting aside cash, adaptable setting aside money and online banking. Nevertheless, they are generally accentuated on computer-generated production with a record, astute cards, e-checks, and web keeping cash. They separated the terminuses of various banks for web production with a recorded assignment. Private fragment banks give the most astonishing internet banking (IB) organizations grabbed subsequently by open splinter banks, inaccessible banks, and old private district banks [14]. The maker recommended a couple of trials that could underwrite towards the more inimitable employment of e-organizations.

Author Analysis - The customers should be taken into demonstrability that the employments made by 
them are sans peril, and there is no notch of any intimidation. Further, they should correspondingly be guaranteed that software engineers can do no tomfoolery to their predispositions.

He surveyed the gradation of the web possession cash officialdoms in Thailand and considered the all-purpose party nature of web background aside cash. The maker used the eight-dimensional superiority model given by David A. Garvin to be unambiguous, implementation, topographies, stubborn eminence, conformance, métier, expediency, and feel and maxim eminence [13]. The examination results indicated that dependability, sanctuary erection, and gen accuracy were the most basic standpoints, and the least domineering was seen in the countryside of the business bank.

Author Analysis - Banks ought to be progressively unswerving, stressed over actions to set up well-being and evidence meticulousness to their customers to deal with worthwhile them in their direction.

\subsection{Studies Related to Technology}

Here, the author elucidated that electronic dealing with utmost enlargement discourses an assortment of different administrations, reaching out from commonplace ATM benefits and direct store to Automatic Bill Payment (ABP), Electronic Funds Transfer (EFT) and PC keeping cash (PC Banking) and thus, "one size fits all" would not work. The use of e-dealing with a record evolution had become speedily in the USA, while others have been grasping it step by step [5]. The makers scrutinized such segments. They suggested that electronic banking enlargements couldn't be totaled into a solitary portrayal.

Author Analysis - The degree of expansion of edealing with a record hinge on how it aids in redeemable time decreases the murmurs, the advancement of ill-advised bookkeeping and balances in charge of data.

The study was intended to detach the target patrons for on the web and compact keeping cash and to take a glimpse at clients' mentality and noncustomers towards e-dealing with record concerning different pieces, for instance, advancement, security comfort, etc. The makers picked an example of 300 respondents from 6 imperative urban networks of China [8]. Security was the essential variable that encouraged Chinese purchasers for the determination of web dealing with a record. In any case, the crucial issues confronted by the patrons of Chinese banks in e-banking were the standpoint on risks, $\mathrm{PC}$ and mechanical aptitudes and absenteeism of care [6], [8].
Author Analysis - Eradication of patron's off-base perceptions and client preparation is the unsurpassed approach to new improvement in the professional area.

\section{Research Methodology}

Presentation of data source: Primary sources will establish the strategy for aggregation of data. A secondary source will base on the individual gathering of customers and people associated with private banks in Delhi and the National Capital Region locale. The author has organized the overview according to the need for the data to be assembled. Auxiliary or secondary sources are a social event of information from the bank website and various destinations related to banking.

Type of survey inculcated: This fuses positioning review for the societal affair of data by collecting data from target respondents, taking care of and dismembering the data. The zone of investigation is the private financial branch that has grasped online banking. In entirety, 194 respondents were reached, obtainable of them, and just 152 respondents have discovered apposite for this investigation in the wake of eradicating the deficient and structured survey sheets.

Tools for analysis: IBM SPSS 22.0 software was used to analyze and test the collected data from the respondents.

\section{Data Analysis \& Findings}

\subsection{Gender and Service Compatibility}

Table 1. Chi-Square Test

\begin{tabular}{|c|c|c|c|}
\hline \multicolumn{4}{|c|}{ Chi-Square (Gender Vs Service Compatibility) } \\
\hline & Value & Df & Sig. \\
\hline Pearson chi-square & 9.124 & 6 & 0.044 \\
\hline
\end{tabular}

With a significance level of 0.05 , it is found that this test is significant, Chi-square value $=9.124, \mathrm{df}=6$, $p=0.044$. The result says that we reject the null hypothesis, which says that around is a momentous alteration amid the "gender and the service compatibility" because the" p"- value is less than the assumed alpha value, i.e., 0.05.

Table 2. MANOVA test

\begin{tabular}{|c|c|c|c|c|c|}
\hline \multicolumn{5}{|c|}{ MANOVA Test (Gender Vs Service Compatibility) } \\
\hline & Value & F & Hypothesis df & Error df & Sig. \\
\hline $\begin{array}{c}\text { Wilks' } \\
\text { Lambda }\end{array}$ & 0.96 & 0.963 & 2 & 54 & 0.048 \\
\hline
\end{tabular}


With a significance level of 0.05 , it is found that this test is significant, Wilk's $=0.96, \mathrm{~F}(2,54)=$ $0.963, p=0.048$. The result says that we reject the null hypothesis, which says that there is a significant difference between the gender and the service compatibility.

With the conclusion of both the tests, it can be said that there is a significant difference between the gender and the service compatibility. This means that the gender of a person may influence the compatibility with the services offered by the bank.

\subsection{Education and Service Compatibility}

Table 3. Chi-Square Test

\begin{tabular}{|c|c|c|c|}
\hline \multicolumn{4}{|c|}{ Chi-Square (Education Vs Service Compatibility) } \\
\hline & Value & Df & Sig. \\
\hline Pearson chi-square & 06.076 & 6 & 0.204 \\
\hline
\end{tabular}

With a significance level of 0.05 , it is found that this test is significant, Chi-square value $=06.076$, $\mathrm{df}=6, \mathrm{p}=0.204$. The result says that we fail to reject the null hypothesis, which says that there is no significant difference between the education and the service compatibility as because the" p"- value is greater than the assumed alpha value, i.e.,0.05. This means that the education level doesn't influence the compatibility with the service. Instead, the interest of the user could have effect on the compatibility.

\section{Recommendations and Suggestions}

Preparing and care among delegates: - It is endorsed that banks should coordinate distinctive getting ready projects for the agents to get careful with the terms of web dealing with a record. After such undertakings, they can make care among the purchasers.

Trade of information on perils and vulnerabilities at reasonable social occasions: - There should be an open-end discourse on the risks and vulnerabilities going over the working of online banking work by the agents in the diverse power get-togethers and meetings.

The bank should create and oversee customer, budgetary master and controller sureness by grasping worldwide accounting benchmarks: -Embracing general standards add some more stars to the brilliance of any association, private banks should power such criteria concerning e-banking, this will improve the altruism of banks among the controller, customers and speculators.

The bank should speculate and prepare for authoritative changes: - Laws concerning IT or advanced laws get change as indicated by the need.
Banks should associate such sort with changes and get stacked with various plans and exercises.

The increasing number of smartphones will change the banking behavior soon: Versatile dealing with a record is getting predominant in online banking. Therefore, this can add some more walks to progress for private banks. The bank is into the adaptable setting aside cash any way it is giving confined components.

More tension should be given on security stress on the web: A couple of individuals are into evil acts of hacking records of customers. This is just the break in the security of the private bank on the web. There should be a couple of measures with a particular ultimate objective to evade such practices. The structure of IT should be rigid.

\section{Conclusion}

Converging on the endeavor, we understood that the internet dealing with a record is undeniably the way ahead for the banks. It offers comfort to customers; meanwhile, it gives cost-cutting to banks by clearing out corporal credentials.

The bank should understand that no edifice is perfect; in any case, a course of action of such a sort ought to be incredibly sheltered. This is a structure that holds an account of focal arguments and customer prosperity. If such a system were not trusted and not strong, the bank would face demonstrable commandments and lose business.

In the wake of thinking about the SWOT assessment, we learned several fortes of banks, for instance, quality customer association, increasingly noticeable accomplishment, 24 hours get to, etc. The private bank should put attempts to build the quantity of strength. In the zone of weakness, we came to know a part of the noteworthy insufficiencies: the nonattendance of cognizance of web dealing with a record among the patrons, obsolesce of development related to security, befuddling frameworks of benefitting web keeping cash workplaces, etc. Banks should concentrate on their weaknesses and should reduce the number of insufficiencies. In the locale of possibilities, some genuine open entryways like $95 \%$ business part of the web business segment is unfamiliar, etc. The bank can fuse these open entryways speedily by proper encasement and strategy in the gravitating towards the future.

\section{Limitation of the Study}

Every investigation is driven under a couple of restrictions, and this assessment is not an exception. As an evaluation relies upon a model, the exposures may not uncover the correct information about the investigation issue; in any case, the most 
extraordinary thought will be taken to pick an explanatory specimen. There may be some inclination in the responses of the respondents, which cannot be blocked totally. The abrupt change in the e-keeping cash deals with over the range of investigation can influence the results. The test size of only 152 was taken from the far-reaching people with the ultimate objective of quintessence, so there can be a distinction amid the test's subsequent outcomes from the total populace.

\section{References}

[1]. Al Shibly, H. H. (2011). An extended Tam Model to evaluate user's acceptance of electronic cheque clearing systems at Jordanian Commercial Banks. Australian Journal of Basic and Applied Sciences, 5(5), 147-156.

[2]. Al-Smadi, M. O., \& Al-Wabel, S. A. (1970). The impact of e-banking on the performance of Jordanian banks. The Journal of Internet Banking and Commerce, 16(2), 1-10.

[3]. Dannenberg and Kellner (1998). "The Bank of Tomorrow with Today's Technology of Internet Banking by Australian Consumers: An Empirical Investigation", International Journal of Bank Marketing, 17,(7), 324-334.

[4]. Kassim, N. M. (2005), "E-Banking Service Quality: Gaps in the Qatari Banking Industry", University of Qatar, Qatar.

[5]. Kolodinsky, J. M., Hogarth, J. M., \& Hilgert, M. A. (2004). The adoption of electronic banking technologies by US consumers. Marketing, 22(4), 238259. https://doi.org/10.1108/02652320410542536

[6]. Krishnamurthy, S. (2006). Introducing E-Markplan: A practical methodology to plan e-marketing activities. Business Horizons, 49(1), 51-60.

Doi: 10.1016/j.bushor.2005.05.008.
[7]. Kuisma, T., Laukkanen, T., \& Hiltunen, M. (2007). Mapping the reasons for resistance to Internet banking: A means-end approach. International Journal of Information Management, 27(2), 75-85.

[8]. Laforet, S., \& Li, X. (2005). Consumers' attitudes towards online and mobile banking in China. The International Journal of Bank Marketing, 23(5), 362380. Doi: 10.1108/02652320510629250.

[9]. Mantel, B. (2000). Why Do Consumers Pay Bills Electronically? An Empirical Analysis, Economic Perspectives of the Federal Reserve Bank of Chicago Q4, pp. 32-48.

[10]. Nasri, W. (2011). Factors influencing the adoption of internet banking in Tunisia. International journal of business and management, 6(8), 143-160.

[11]. Thamarai, N., Senthil, A. B., \& Siva, M. (2010). Customer's Choice amongst Self Service Technology (SST) Channels in Retail Baking: A Study Using Analytical Hierarchy Process (AHP). Journal of Internet Banking and Commerce, 15(2).

[12]. Pikkarainen, T., Pikkarainen, K., Karjaluoto, H., \& Pahnila, S. (2004). Consumer acceptance of online banking: an extension of the technology acceptance model. Internet Research, 14(3), 224-235. Doi: $10.1108 / 10662240410542652$.

[13]. Leelapongprasut, P., Praneetpolgrang, P., \& Paopun, N. (2005, November). A quality study of internet banking in Thailand. In Proceedings of the 4th International Conference on eBusiness. Bangkok, Thailand (pp. 6-1).

[14]. Sarangapani, A., \& Mamatha, T. (2008). E-banking: Implementation and Challenges. Icfai University press Professional Bankers, 8(5), 39-42.

[15]. Milind, S. (1999). Adoption of Internet banking by Australian consumers: an empirical investigation. The International Journal of Bank Marketing, 17(7), 324334. http://doi.org/10.1108/02652329910305689

[16]. Siam, A. Z. (2006). Role of the electronic banking services on the profits of Jordanian banks. American Journal of Applied Sciences, 3(9), 1999-2004. 